\title{
Lanthanum deposition in the gastric mucosa in a patient treated with haemodialysis
}

\author{
Yasutoshi Shiratori, Noriaki Oguri
}

Department of

Gastroenterology, St. Luke's International Hospital, Tokyo, Japan

\section{Correspondence to} Dr Yasutoshi Shiratori, shiraya@luke.ac.jp

Accepted 1 May 2019

\section{DESCRIPTION}

A 74-year-old man presented with chronic stomach discomfort and an episode of malaise that was associated with anaemia. The patient had a history of surgery for kidney cancer and was undergoing haemodialysis owing to a 7-year history of chronic renal failure; he had also been treated with lanthanum carbonate hydrate (62 months). Physical examination revealed mild pallor in his palpebral conjunctiva; however, no other abnormalities were observed. Plain CT revealed an area of high absorption along the lesser curvature of the stomach body (figure 1). Oesophagogastroduodenoscopy was subsequently performed. Although there were no signs of ulcers or tumours, white regional lesions, similar to those observed in cases involving xanthoma, were observed along the lesser curvature of the stomach body to the stomach antrum

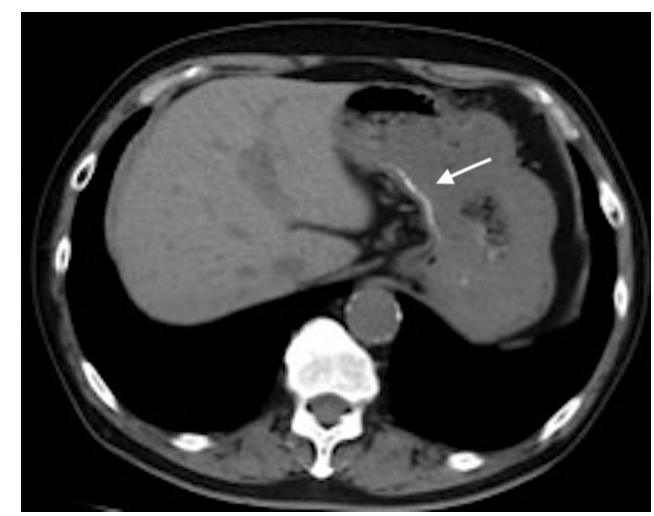

Figure 1 Plain CT revealed lanthanum deposition as an area of high-density absorption in the gastric mucosa (arrow).

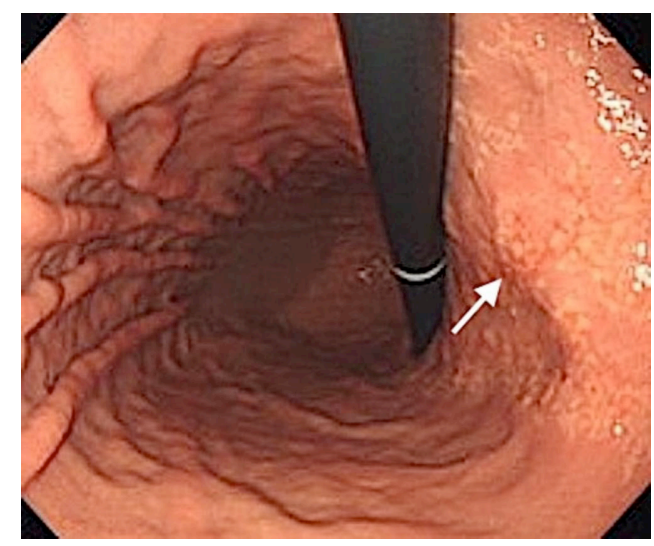

Figure 2 The white lesions were widely observed along the lesser curvature of the gastric body. The arrow indicates the biopsy sites.

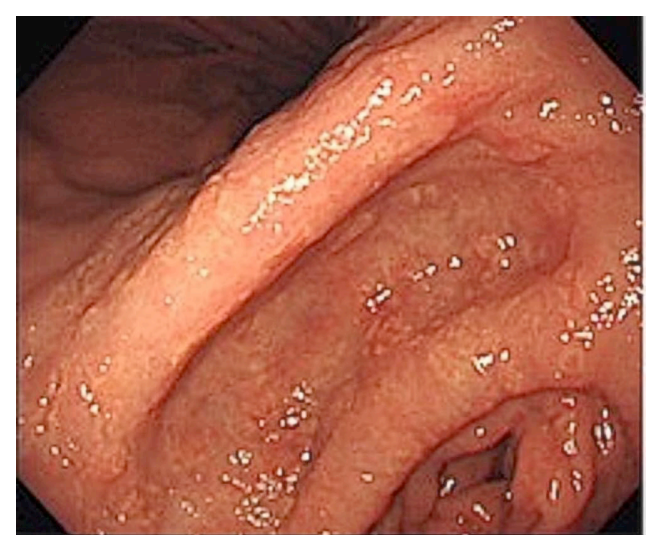

Figure 3 The white lesions extended to the gastric antrum.

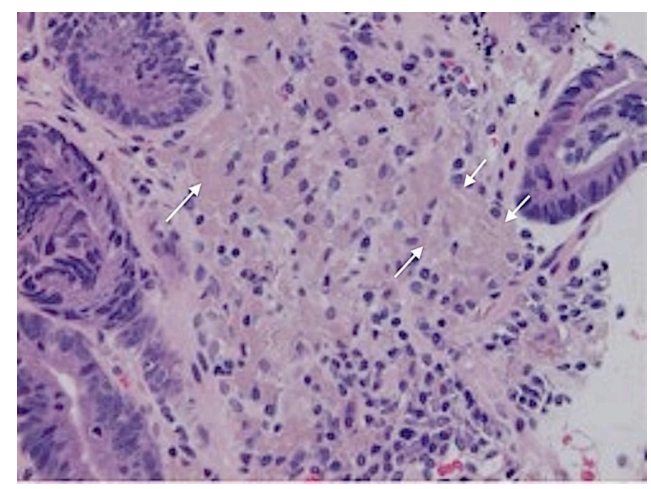

Figure 4 Biopsy of the white lesion revealed increased histiocytes and lanthanum deposition within the lamina propria (arrow). Regenerative changes and intestinal metaplasia were found in gastric mucosa.

(figures 2 and 3). Atrophic changes were not found in most of the stomach body, but map-like redness was observed along the lesser curvature of the stomach body to the stomach angle. Histopathological analysis of the lesions showed increased histiocytes and lanthanum deposition (figure 4). In terms of gastric mucosa, regenerative changes and intestinal metaplasia were found. As the patient was taking lanthanum carbonate, we believed that the white lesions were due to lanthanum deposition. Lanthanum deposition in the stomach was

Learning points

- Plain CT revealed an area of high absorption in stomach due to lanthanum deposition.

- Lanthanum deposition in stomach also occurs in Helicobacter-negative patients. 
classified as the endoscopic feature, diffuse whitish mucosa in the gastric body and annular whitish mucosa were observed in this case. ${ }^{1}$ It has been pointed out that lanthanum deposition may be associated with atrophic mucosa, intestinal metaplasia or foveolar hyperplasia. ${ }^{2-4}$ Although not all, those mucosal changes were thought to be associated with Helicobacter pylori infection. In our patient, anti-H. pylori immunoglobulin $\mathrm{G}$ antibody level was $<3 \mathrm{U} / \mathrm{mL}$, and pepsinogen-based test was positive, so this patient was thought as the prior $H$. pylori infection. This case was a typical case of lanthanum deposition with regenerative changes and intestinal metaplasia in the stomach.

Contributors NO and YS performed endoscopy. YS wrote and drafted this paper.

Funding The authors have not declared a specific grant for this research from any funding agency in the public, commercial or not-for-profit sectors.
Competing interests None declared.

Patient consent for publication Obtained.

Provenance and peer review Not commissioned; externally peer reviewed.

\section{REFERENCES}

1 Murakami N, Yoshioka M, Iwamuro M, et al. Clinical characteristics of seven patients with lanthanum phosphate deposition in the stomach. Intern Med 2017:56:2089-95.

2 Ban S, Suzuki S, Kubota K, et al. Gastric mucosal status susceptible to lanthanum deposition in patients treated with dialysis and lanthanum carbonate. Ann Diagn Pathol 2017;26:6-9.

3 Hattori K, Maeda T, Nishida S, et al. Correlation of lanthanum dosage with lanthanum deposition in the gastroduodenal mucosa of dialysis patients. Pathol Int 2017:67:447-52.

4 Iwamuro M, Urata H, Tanaka T, et al. Lanthanum deposition corresponds to white lesions in the stomach. Pathol Res Pract 2018;214:934-9.

Copyright 2019 BMJ Publishing Group. All rights reserved. For permission to reuse any of this content visit https://www.bmj.com/company/products-services/rights-and-licensing/permissions/

BMJ Case Report Fellows may re-use this article for personal use and teaching without any further permission.

Become a Fellow of BMJ Case Reports today and you can:

- Submit as many cases as you like

Enjoy fast sympathetic peer review and rapid publication of accepted articles

- Access all the published articles

Re-use any of the published material for personal use and teaching without further permission

For information on Institutional Fellowships contact consortiasales@bmjgroup.com

Visit casereports.bmj.com for more articles like this and to become a Fellow 